\title{
IN SITU DENITRIFICATION OF GROUND WATER USING THIOSPHAERA PANTOTROPHA
}

\author{
Sudhir Kumar ${ }^{* 1}$ and A.B.Gupta*
}

\begin{abstract}
A two well model was fabricated to study the application of Thiosphaera pantotropha for in situ denitrification. The effect of varying $\mathrm{C} / \mathrm{N}$ (Carbon/Nitrogen) ratio (0.922.5) on denitrification was observed with sodium acetate as a carbon source. At $\mathrm{C} / \mathrm{N}$ ratio of 2.1 the reduction in nitrate nitrogen was sufficient to bring it below WHO limits of $10 \mathrm{mg} / \mathrm{l}$ from an initial concentration of $50 \mathrm{mg} / \mathrm{l}$. At a $\mathrm{C} / \mathrm{N}$ ratio of 2.3 , the treated water nitrate was reduced to zero. DO during various phases of experiment ranged from 5.58 to $2.86 \mathrm{mg} / \mathrm{l}$ indicating that highly aerobic condition prevailed throughout. As the $\mathrm{C} / \mathrm{N}$ increased from 0.92 to 2.5 . The head loss increased from 30 to $72 \mathrm{~cm}$.
\end{abstract}

KEY WORDS : Groundwater, in situ denitrification, acetate, T.Pantotropha

\section{INTRODUCTION}

Ground water is one of the major sources of drinking water in Rajasthan,India, which caters $70 \%$ water needs of the state. Nearly the whole state is suffering from the problem of high nitrates with concentrations ranging from 30 to $1000 \mathrm{mg} / \mathrm{l}$ in groundwater(1),(2). Nitrite removal technologies can be broadly classified as Operational, Physicochemical and Biological. The biological process

\footnotetext{
* Professor Civil Engg. Deptt.,MNIT Jaipur ,Rajasthan,India

1.Author for correspondence
}

can be further classified into two groups: 1.Pump and treat method and 2. In situ denitrification (3),(4).

The in situ denitrification advantage as compared to surface technologies is the fact that supplementary treatment after denitrification is carried out in aquifer including filtration and bacterial die off, removal of organic residuals by biodegradation and adsorption. In situ denitrification seems to have a great promise to reduce the exposure of nitrates causing methemoglobinemia.

Thiosphaera pantotropha is a non-motile, gram negative coccus $(0.7 \mathrm{x} \quad 0.9 \mu \mathrm{m})$ which is frequently seen in pairs or long chains. This isolate was found capable of mixotrophic and heterotrophic growth on wide range of substrates, thereby proving itself as a facultatively anaerobic, facultatively autotroph (5),(6). Gupta, used $T$. pantotropha in mixed cultures in fixed and suspended growth systems. The system proved superior to the conventional nitrogen removal strategies(7),(8).This paper describes a laboratory 2-well model used to evaluate the efficacy of $T$. pantotropha to carry out in situ denitrification using acetate. 
Proc. of the Fourth International Conference on Advances in Civil, Structural and Environmental Engineering - ACSEE 2016. Copyright $@$ Institute of Research Engineers and Doctors. All rights reserved.

ISBN: 978-1-63248-114-6 doi: 10.15224/ 978-1-63248-114-6-23

\section{The Experimental Set Up}

A two wells model was fabricated by placing two Aluminium Square Brackets of cross section $7.5 \mathrm{~cm}$ $\mathrm{x} 3.25 \mathrm{~cm}$ on two sides of model. Two wells were provided at two ends of the model, serving as inlet and discharge wells. A third well, the injection well, was placed near the inlet well to feed bacterial culture at the time of starting the reactor. There was no other use of this well therefore the model was considered to be effectively a two well model. .A feed reactor of $100 \mathrm{~L}$ capacity was used and two reactors of $10 \mathrm{~L}$ each were fabricated with perspex sheet, one for overflow water collection and another for treated water collection. The model was filled with sand simulating the ground conditions in Rajasthan.

T.pantotropha, obtained from Technical University,Delft,Netherlands, was maintained on petri plates in a medium prescribed by Robertson for its growth (9).

The initial difference in head between water levels in inlet well and outlet tube attached to discharge well (the headloss) was kept at $30 \mathrm{~cm}$. A constant flow rate of $220 \mathrm{ml} / \mathrm{hr}$ was maintained.The system was operated under these conditions for one week allowing bacterial growth to take place in the soil column. Synthetic feed was prepared with tap water with $\mathrm{C} / \mathrm{N}$ ratio ranging from $0.92-2.5$ having sodium acetate as a carbon source and $\mathrm{KNO}_{3}$ as the source of nitrate.Seven different compositions were tried. A constant nitrate nitrogen concentration of $50 \mathrm{mg} / \mathrm{l}$ was maintained and $\mathrm{C} / \mathrm{N}$ was varied by changing only the organic concentration. Table 1 gives media compositions which were used to study the effects of different parameters on the performance of in situ denitrification model .
Table-1 Composition of synthetic nitrate-rich water for denitrification

\begin{tabular}{|c|c|c|c|c|c|}
\hline $\mathbf{S}$. & $\begin{array}{c}\mathbf{C H}_{\mathbf{3}} \mathbf{C O O N a} \\
\mathbf{( g / 5 0} \mathbf{l})\end{array}$ & $\begin{array}{c}\mathbf{K N O}_{\mathbf{3}} \\
(\mathbf{g} / \mathbf{5 0} \mathbf{l})\end{array}$ & $\begin{array}{c}\mathbf{C} \\
(\mathbf{m g} \\
\mathbf{( \mathbf { l } )}\end{array}$ & $\begin{array}{c}\mathbf{N O}_{\mathbf{3}^{-}} \mathbf{N} \\
(\mathbf{m g} / \mathbf{l})\end{array}$ & $\mathbf{C / N}$ \\
\hline 1 & 7.86 & 18 & 46 & 50 & 0.92 \\
\hline 2 & 9.35 & 18 & 55 & 50 & 1.1 \\
\hline 3 & 12.81 & 18 & 75 & 50 & 1.5 \\
\hline 4 & 17.08 & 18 & 100 & 50 & 2.0 \\
\hline 5 & 14.0 & 18 & 105 & 50 & 2.1 \\
\hline 6 & 19.64 & 18 & 115 & 50 & 2.3 \\
\hline 7 & 21.35 & 18 & 125 & 50 & 2.5 \\
\hline
\end{tabular}

In the beginning the reactor was run at a $\mathrm{C} / \mathrm{N}$ ratio of 0.92 for six weeks. Observations were recorded daily for COD (Chemical Oxygen Demand) and nitrate in the treated water. It was found that pseudo steady-state was achieved in 12 days with nitrate values becoming almost constant with the variation between values being less than $5 \%$ for nitrate on three consequtive days. After achieving the pseudo steady state the system was monitored daily for $\mathrm{pH}$, alkalinity, temperature, COD, nitrate, in both influent and effluent water samples.

$$
\text { At every subsequent } \mathrm{C} / \mathrm{N} \text { ratio daily }
$$

Monitoring of only effluent nitrate was done initially and when it was observed that pseudo steady state is achieved w.r.t. $\mathrm{NO}_{3}$ concentration, detailed monitoring of influent and effluent water samples was carried out for parameters like pH, alkalinity, DO (Dissolved Oxygen), $\mathrm{COD}$, temperature, headloss \& $\mathrm{NO}_{3}-\mathrm{N}$ monitored daily. It was found that the reactor took 9-12 days at various $\mathrm{C} / \mathrm{N}$ ratios to achieve pseudo steady state, hence the reactor was run for a total of 24 days at each $\mathrm{C} / \mathrm{N}$ ratio.

\section{Process monitoring}

Samples were analyzed for various parameters as per Standard Methods for $\mathrm{NO}_{3}-\mathrm{N}$, Alkalinity \& $\mathrm{COD}$, Temperature, DO , pH (10). Alkalinity was measured by titrating against standard acid, COD by close-reflux 
Proc. of the Fourth International Conference on Advances in Civil, Structural and Environmental Engineering - ACSEE 2016. Copyright $@$ Institute of Research Engineers and Doctors. All rights reserved. ISBN: 978-1-63248-114-6 doi: 10.15224/ 978-1-63248-114-6-23

method and $\mathrm{NO}_{3}-\mathrm{N}$ by $\mathrm{UV}$ method by measuring absorption at $220 \mathrm{~nm}$.

\section{RESULTS AND DISCUSSIONS}

Stoichiometrically a $\mathrm{C} / \mathrm{N}$ ratio of 1.08 is sufficient for complete denitrification. However, in laboratory column experiments due to presence of DO in soil other routes of electron transfer may require much higher carbon source than that calculated stoichiometrically to bring down nitrates to the desired levels.
Table-2 shows average pseudo steady state values of various parameters at different $\mathrm{C} / \mathrm{N}$ ratios using acetate as the sole carbon source with standard deviations indicated in parentheses. Fig.-1 shows the effect of COD loading rate on removal of nitrates and COD removal. The plot between COD removal rate and COD applied follows a straight-line relationship with a regression coefficient of 0.98 . Further, plot between nitrate removal rate and applied nitrate also shows a straight-line relationship. This indicates first order reaction kinetics for the full range of experimentation.

Table - 2 Consolidated pseudo-steady state parameters at various $\mathrm{C} / \mathrm{N}$ ratios

\begin{tabular}{|c|c|c|c|c|c|c|c|c|c|c|c|c|}
\hline \multirow{2}{*}{$\begin{array}{l}\mathrm{C} / \mathrm{N} \\
\text { ratio }\end{array}$} & \multicolumn{2}{|l|}{ PH } & \multicolumn{2}{|c|}{ Alkalinity ( $\mathrm{mg} / \mathrm{l})$} & \multirow{2}{*}{$\begin{array}{l}\text { Head } \\
\text { drop } \\
(\mathrm{Cm})\end{array}$} & \multirow{2}{*}{$\begin{array}{c}\text { Temp. } \\
{ }^{0} \mathrm{C}\end{array}$} & \multicolumn{2}{|r|}{$(\mathrm{mg} / \mathrm{l})$} & \multicolumn{2}{|c|}{$\mathrm{COD}(\mathrm{mg} / \mathrm{l})$} & \multicolumn{2}{|c|}{$\mathrm{NO}_{3}-\mathrm{N}(\mathrm{mg} / \mathrm{l})$} \\
\hline & Influent & effluent & Influent & effluent & & & Influent & effluent & Influent & effluent & Influent & effluent \\
\hline 0.92 & $\begin{array}{c}7.18 \\
(0.037)\end{array}$ & $\begin{array}{c}7.38 \\
(0.037)\end{array}$ & $\begin{array}{l}243.69 \\
(1.109)\end{array}$ & $\begin{array}{l}251.38 \\
(1.502)\end{array}$ & 30 & $\begin{array}{c}20.01 \\
(1.045)\end{array}$ & $\begin{array}{c}5.88 \\
(0.037)\end{array}$ & $\begin{array}{c}5.58 \\
(0.037)\end{array}$ & $\begin{array}{c}122.93 \\
(0.917)\end{array}$ & 0 & $\begin{array}{c}50.63 \\
(0.588)\end{array}$ & $\begin{array}{c}37.79 \\
(0.693)\end{array}$ \\
\hline 1.1 & $\begin{array}{c}7.32 \\
(0.043)\end{array}$ & $7.6 \quad(0)$ & $\begin{array}{l}268.92 \\
(1.754)\end{array}$ & $\begin{array}{l}284.92 \\
(1.754)\end{array}$ & 36 & $\begin{array}{l}21.76 \\
(2.084)\end{array}$ & $\begin{array}{l}5.8 \\
(0)\end{array}$ & $\begin{array}{c}5.36 \\
(0.050)\end{array}$ & $\begin{array}{c}146.73(0 \\
.728)\end{array}$ & 0 & $\begin{array}{c}50.47 \\
(0.513)\end{array}$ & $\begin{array}{c}32.39 \\
(0.873)\end{array}$ \\
\hline 1.5 & $\begin{array}{c}7.82 \\
(0.043)\end{array}$ & $\begin{array}{c}8.17 \\
(0.043)\end{array}$ & $\begin{array}{l}303.38 \\
(1.502)\end{array}$ & $\begin{array}{c}320.92 \\
(1.754)\end{array}$ & 40 & $\begin{array}{c}16.83 \\
(0.835)\end{array}$ & $\begin{array}{l}5.8 \\
(0)\end{array}$ & $\begin{array}{l}5.1 \\
(0)\end{array}$ & $\begin{array}{c}200.41(1 \\
.231)\end{array}$ & 0 & $\begin{array}{l}50.439 \\
(0.247)\end{array}$ & $\begin{array}{c}29.73 \\
(1.062)\end{array}$ \\
\hline 2 & $\begin{array}{c}8.03 \\
(0.048)\end{array}$ & $\begin{array}{c}8.36 \\
(0.048)\end{array}$ & $\begin{array}{c}310.8 \\
(1.922)\end{array}$ & $\begin{array}{l}335.07 \\
(1.754)\end{array}$ & 56 & $\begin{array}{c}6.98 \\
(1)\end{array}$ & $\begin{array}{c}5.99 \\
(0.027)\end{array}$ & $\begin{array}{c}4.7 \\
(0.040)\end{array}$ & $\begin{array}{c}265.84(0) \\
.860)\end{array}$ & 0 & $\begin{array}{c}50.3 \\
(0.406)\end{array}$ & $\begin{array}{c}21.01 \\
(1.479)\end{array}$ \\
\hline 2.1 & $\begin{array}{c}8.16 \\
(0.048)\end{array}$ & $\begin{array}{c}8.59 \\
(0.064)\end{array}$ & $\begin{array}{c}320 \\
(0)\end{array}$ & $\begin{array}{l}342.76 \\
(1.921)\end{array}$ & 61 & $\begin{array}{c}10.48 \\
(1.069)\end{array}$ & $\begin{array}{c}5.78 \\
(0.037)\end{array}$ & $\begin{array}{c}4.14 \\
(0.087)\end{array}$ & $\begin{array}{c}281.06(1 \\
.426)\end{array}$ & 0 & $\begin{array}{c}50.63( \\
0.570)\end{array}$ & $\begin{array}{c}9.06 \\
(0.370)\end{array}$ \\
\hline 2.3 & $\begin{array}{c}8.27 \\
(0.043)\end{array}$ & $\begin{array}{c}8.78 \\
(0.037)\end{array}$ & $\begin{array}{l}367.38 \\
(1.502)\end{array}$ & $396 \quad(0)$ & 68 & $\begin{array}{c}21.23 \\
(1.786)\end{array}$ & $\begin{array}{l}6.1 \\
(0)\end{array}$ & $\begin{array}{c}3.94 \\
(0.051)\end{array}$ & $\begin{array}{c}306.03(1 \\
.737)\end{array}$ & 0 & $\begin{array}{c}50.28 \\
(0.285)\end{array}$ & 0 \\
\hline 2.5 & $\begin{array}{c}8.46 \\
(0.048)\end{array}$ & $\begin{array}{c}8.83 \\
(0.143)\end{array}$ & $\begin{array}{l}386.15 \\
(2.075)\end{array}$ & $\begin{array}{l}414.15 \\
(2.075)\end{array}$ & 72 & $\begin{array}{l}19.38 \\
(2.019)\end{array}$ & $\begin{array}{c}6.03 \\
(0.050)\end{array}$ & $\begin{array}{c}2.86 \\
(0.354)\end{array}$ & $\begin{array}{c}333.55(1 \\
.189)\end{array}$ & $\begin{array}{c}29.32 \\
(2.534)\end{array}$ & $\begin{array}{c}50.94 \\
(0.539)\end{array}$ & 0 \\
\hline
\end{tabular}

Average value (Standard Deviation) 
Proc. of the Fourth International Conference on Advances in Civil, Structural and Environmental Engineering - ACSEE 2016. Copyright $@$ Institute of Research Engineers and Doctors. All rights reserved.

ISBN: 978-1-63248-114-6 doi: 10.15224/ 978-1-63248-114-6-23

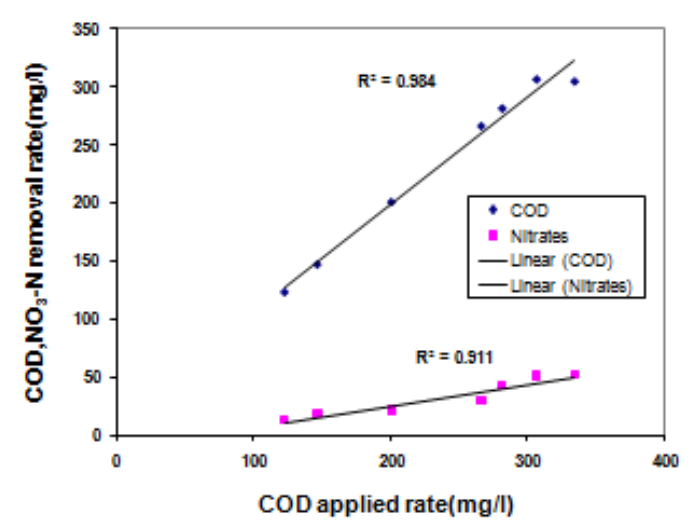

Fig. 1 A plot between COD applied v/s $\mathrm{COD}, \mathrm{NO}_{3}-\mathrm{N}$ removal rate

The influent COD at all $\mathrm{C} / \mathrm{N}$ ratios varied from 122 to 334 $\mathrm{mg} / \mathrm{l}$. There was no COD in the effluent except at a $\mathrm{C} / \mathrm{N}$ ratio of 2.5 which is indication of addition of excess carbon. At such organic loading the COD in treated water would increase the post treatment requirements tremendously and as such this ratio should strictly be avoided.

The influent nitrate concentration varied within about $1 \%$ from average nitrate value of 50.94 at all $\mathrm{C} / \mathrm{N}$ ratios. Whereas the effluent achieved the permissible value of nitrate in form of nitrogen at a $\mathrm{C} / \mathrm{N}$ ratio of 2.1 beyond which effluent nitrate reduced to zero. Since at a $\mathrm{C} / \mathrm{N}$ of 2.5 organics started infiltering, it is recommended that running the process at $\mathrm{C} / \mathrm{N}$ ratio of 2.1 would be ideal as it fulfils the treated water nitrate requirements as well as provides a good factor of safety against the ingress of organics into treated water. Since this aquifer used for experiment was shallow (depth of $1.0 \mathrm{~m}$ ), the soil was highly aerated and DO was high all through the experiment. It is expected that in natural aquifer, this value would drop down and the competition would shift more in favour of nitrate as final electron acceptor resulting in still better results. However, non-inhibition of T. pantotropha under highly aerobic conditions for denitrification was confirmed and hence the application of it for Rajasthan soils can prove to highly advantageous.

In this study dissolved oxygen in the effluent was as high as $5.58 \mathrm{mg} / \mathrm{l}$. Robertson showed that denitrification was observed in T. pantotropha even at $80 \%$ air saturation and increased on lowering of DO till it attained a value of $30 \%$ air saturation where it was almost equal to its value under anoxic conditions (9). Gupta (1992) and Kshirsagar (1994) confirmed the properties of aerobic denitrification using $T$. pantotropha in mixed cultures in activated sludge process where influent $\mathrm{NO}_{3}$ $\mathrm{N}$ was $425 \mathrm{mg} / \mathrm{l}$ and DO remained more than $2.5 \mathrm{mg} /$ (11)(12). Korner,H and Zumft,W.G.(1989) studied denitrification activity for T.pantotropha, Erythrobacter $s p$ or complex communities of fresh water sediment under full or nearly full aerobiosis(13). Aerobic denitrification could not take place in P.stutzeri, as neither nitrate reductase nor nitrite reductase was synthesized at DO concentrations above $5 \mathrm{mg} / \mathrm{l}$. Only $\mathrm{N}_{2} \mathrm{O}$ was consequently present in small amounts in fully aerobic cells. Thus $T$. pantotropha would be of special advantage in shallow aquifers where DO can exceed 5.0 as studied by above researchers.

The $\mathrm{pH}$ of treated water varied from 7.38 to 8.83. It increased as $\mathrm{C} / \mathrm{N}$ ratio increased as higher denitrification rates were achieved. Increase in $\mathrm{pH}$ signified generation of alkalinity at every $\mathrm{C} / \mathrm{N}$ ratio. Korner and Zumft (1989)who observed no formation of $\mathrm{N}_{2} \mathrm{O}$ over a $\mathrm{pH}$ of 7.2 (13).

The alkalinity in the effluent rose from 251 to $414 \mathrm{mg} / \mathrm{l}$ as the $\mathrm{C} / \mathrm{N}$ ratio increased from 0.9 to 2.5 . The fluctuation in the average values of alkalinity was less than $1 \%$ at all individual $\mathrm{C} / \mathrm{N}$ ratios. The ratio of 
Proc. of the Fourth International Conference on Advances in Civil, Structural and Environmental Engineering - ACSEE 2016. Copyright $@$ Institute of Research Engineers and Doctors. All rights reserved. ISBN: 978-1-63248-114-6 doi: 10.15224/ 978-1-63248-114-6-23

alkalinity generated to $\mathrm{NO}_{3}-\mathrm{N}$ removed varied from 0.55

to 0.90 .

The head loss increased from 30 to $72 \mathrm{~cm}$ as $\mathrm{C} / \mathrm{N}$ ratio increased from 0.92 to 2.5 . The higher head loss with increased $\mathrm{C} / \mathrm{N}$ ratios indicated growth of bacteria.

Fig. 2 represents a plot between nitrate removal efficiency v/s $\mathrm{C} / \mathrm{N}$ ratios. It shows that as $\mathrm{C} / \mathrm{N}$ ratio increases the nitrate removal efficiency also increases.

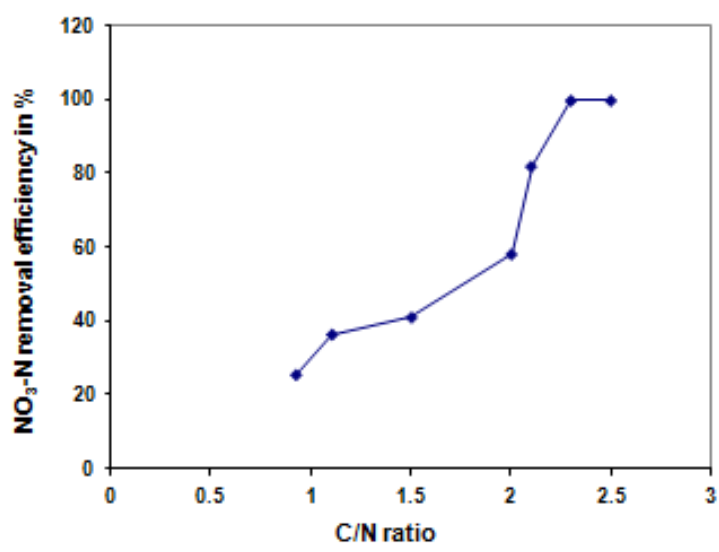

Fig. 2 A plot of nitrate removal efficiency v/s $\mathrm{C} / \mathrm{N}$ ratio

\section{CONCLUSIONS}

A judicious use of in situ technology using $T$. pantotropha and a suitable electron donor indicated to provide a solution to restore wells abandoned due to the presence of high nitrates. The $\mathrm{C} / \mathrm{N}$ ratio proved to be very important parameter for controlling the growth of $T$. pantotropha..Both COD and nitrate removal showed first order reactions.

The higher head loss with increasing $\mathrm{C} / \mathrm{N}$ ratios indicated higher growth of bacterium. It confimed the importance of T. pantotropha for denitrification in fully aerated soils with DO ranging from $5.5 \mathrm{mg} / \mathrm{l}$ to $2.86 \mathrm{mg} / \mathrm{l}$ The soils were highly aerated and DO was high all through the experiment. It is expected that in natural aquifers,where
DO levels are expected to be lower than that of experimental row column.

\section{References:}

1. PHED, "Habitation Survey of Water Quality", Public Health Engineering Department, Rajasthan,1991.

2. S.S.Dhindsa, N.Bhargava and R.K.Bhargava, "Surface and Ground Water Quality in Kota", J.IWWA, 216,3, 291-294,1984.

3. S.Liang, M.A.Mann, G.A.Guter, P.H.S. Kim and D.L.Hardan, "Nitrate Removal from Contaminated Ground Water", JAWWA, 91,2, 79-90,1999.

4. A.Kapoor and T.Viraraghavan, "Nitrate Removal from Drinking Water - Review", Journal of Environmental Engineering, 123, 4, 371-380,1997.

5. J.W.B.Moir, D.J.Richardson, and S.J. Ferguson, "The Expression of Reducx Proteins of Denitrification in Thiosphaera pantotropha Grown with Oxygen, Nitrate and Nitrons Oxide as Electron Acceptor", Arch Microbiol, 164, 43-49,1995.

6. A.B.Gupta, "Thiosphaera pantotropha : A Sulphur Bacterium Capable of Simultaneous Heterotraphic Nitrification and Aerobic Denitrification", Enzyme and Microbiol Technology, Elsevier Sci, N-York,1997.

7. A.B.Gupta and S.K.Gupta, Simultaneous carbon and nitrogen removal in a mixed culture aerobic RBD biofilm. Water Research,33(2),555-56,1999.

8. A.B.Gupta and S.K. Gupta, Simultaneous carbon and nitrogen removal from high strength domestic wastewater in an aerobic RBC biofilm. Water Research,35(7),1714-1722,2001.

9. L.A.Robertson, , W.J van Niel, RA.M. Torremans, and J.G.Kuenen, "Simultaneous Nitrification and Denitrification in Aerobic Chemostat Cultures of Thiosphaera pantotropha Applied and Environmental Microbiology", 54, 2812-2818,1988.

10. APHA, AWWA, WPCF, "Standard Methods for Examination of Water and Waste Water", 17th ed. Washington, DC, American Public Health Association, 1989 .

11. A.B.Gupta, M.Kshirsagar, and S.K.Gupta, Dissimilatory Nitrate Reduction Under Aerobic Conditions by $T$. pantotropha Dominated Activated Sludge, Int.J.Envron.Studies,40,100,1992.

12. M.Kshirsagar, A.B.Gupta, and S.K. Gupta, "Aerobic denitrification studies on activated sludge mixed with Thiosphaera pantotropha. Environ.Technol.,16,3543,1994.

13. H.Korner and W.G. Zumfit, "Expression of Denitrification Enzymes in Response to the Dissolved Oxygen Level and Respiratory Substrate in Continuous Culture of Pseudomonas stutzeri". Appl. Environ. Microbiol., 55, pp. 1670-1676,1989. 